\title{
On "Colonial scientific-medical documentary films and the legitimization of an ideal state in post-war Spain," or the importance of being cited
}

Dear editors,

When reading the paper "Colonial scientific-medical documentary films and the legitimization of an ideal state in post-war Spain," published in the second issue of the 24th volume of this journal, the readers of Manguinhos [História, Ciências, Saúde - Manguinhos] - especially those who are not familiar with the Spanish language - may be led to believe two things. First, that this is the first investigation that uses medical documentaries on the Spanish-African colonies as historical sources. Second, that it is the first study framing those sources within the ideology and symbolic representations of the early Francoist regime. This letter aims to dismiss such beliefs, and warmly thanks the editorial board of the journal for providing the opportunity to do so.

In 2009, an article of mine was published in the Spanish medical history journal Medicina \& Historia (indexed in PubMed, Scopus, Scimago etc.) with the title "Imperio enfermizo: la singular mirada mórbida del primer franquismo en los documentales médicos sobre Marruecos y Guinea" (A sickly empire: the singular morbid gaze of early Francoism in medical documentary films on Morocco and Guinea). ${ }^{1}$ A few months earlier, this paper had been granted the XL Prize by the Fundación Uriach 1838 (publisher of Medicina \& Historia), the oldest and best-funded prize for medical history research in Spain. The main aim of my article was to develop an innovative interpretation of the early Francoist regime as a transnational Spanish-African ideological and political reality. For that purpose, I used two medical documentaries, Enfermos en Ben Karrich and Los enfermos de Mikomeseng, the first dealing with tuberculosis patients in the Spanish Protectorate in Morocco and the second, with leprosy patients in Spanish Guinea. I argued that Africa had been the central space for the symbolic representation of early Francoism and showed how tuberculosis and leprosy were metaphorically used to pathologize those Spaniards and Africans who either reluctantly supported the regime or opposed it.

A side contribution to that first article appeared three years later. On the occasion of the 100th anniversary of the establishment of the Spanish Protectorate in Morocco, the Arabic studies journal Awraq, also based in Spain, asked me to prepare a contribution to a monographic dossier on that topic, in which I should specifically deal with issues related

\footnotetext{
${ }^{1}$ MARTíNEZ, Francisco Javier. Imperio enfermizo: la singular mirada mórbida del primer franquismo en los documentales médicos sobre Marruecos y Guinea. Medicina \& Historia, cuarta época, n.4, p.1-15. 2009. Available in open-access at: http://www.fu1838.org/pdf/2009-4.pdf.
} 
to medicine and health. My paper "La medicina y la sanidad en el Protectorado español en Marruecos: apuntes iconográficos" (Medicine and public health in the Spanish Protectorate in Morocco: iconographic sketches) ${ }^{2}$ used maps, images, and films to propose new understandings of those topics and of Spanish domination in Morocco in general. The last of the three sections of my paper consisted of an analysis of the medical documentary Médicos de Marruecos in view of the dominant ideology in early Francoist Spain. More precisely, it was argued that doctors working in Spanish Morocco were represented as symbols of Francoism and Franco himself, especially countryside doctors (for which the Arabic word tebib was used). In its own singular way, Francoism monopolized the linguistic field of health, medicine, and normality while confining its enemies to those of disease and abnormality.

I do not mean to suggest that the publication of these two papers - or of many others in which I have dealt with various aspects of medicine, health, and humanitarianism in nineteenth- and twentieth-century Morocco - grants me any sort of monopoly on sources or topics. Research is always open to anyone willing to make new contributions. Moreover, I am not so naïve to think that I have exhausted the particular sources and topics to which this letter is making reference. Finally, I do not intend that other authors share my interpretations and methodological tools: sciences, natural or human, are made of and through debates and discussions, and significant advances in them are sometimes a direct result of the conflict of ideas. Actually, the authors of the paper "Colonial scientific-medical documentary films and the legitimization of an ideal state in post-war Spain," Carlos Tabernero, Isabel JiménezLucena, and Jorge Molero-Mesa, suggest different interpretations about Francoism and medical documentaries on Spanish-African colonies from those I propose in my articles. They also address new aspects of the problem and use a larger set of film sources. In spite of all this, I think it is reasonable to demand that a paper dealing with that topic and using those sources cite my publications and include the references in the bibliography at the end of the text.

This is not only a personal opinion. Important associations of historians have issued guidelines or orientations for good practice that could be used as arguments in the present case. For example, the American Historical Association uploads to its website a regularlyupdated version of its Statement on Standards of Professional Conduct. In one of its sections, it is argued that "even in textbooks a historian should acknowledge the sources of recent or distinctive findings and interpretations." In addition, the Statement claims that:

all historians share responsibility for defending high standards of intellectual integrity. When appraising manuscripts for publication, reviewing books or evaluating peers for placement, promotion and tenure, scholars must evaluate the honesty and reliability with which the historian uses primary and secondary source materials. Scholarship flourishes in an atmosphere of openness and candor, which should include the scrutiny and public discussion of academic deception. ${ }^{3}$

\footnotetext{
${ }^{2}$ MARTÍNEZ, Francisco Javier. La medicina y la sanidad en el Protectorado español en Marruecos: apuntes iconográficos. Awraq, n.5-6, p.135-156. 2012. Available in open-access at: http://www.awraq.es/blob.aspx? $\mathrm{idx}=5 \&$ nId=81\&hash=6d57be6eb1b80ab1bb7f56870a16c0d0.

3 American Historical Association. "Statement on Standards of Professional Conduct (updated 2017)." Available at: https://www.historians.org/jobs-and-professional-development/statements-standards-andguidelines-of-the-discipline/statement-on-standards-of-professional-conduct.
} 
In the Spanish context to which the authors of the paper and myself belong, the Asociación de Historia Contemporánea (AHISTCON) has recently issued a Comunicado de la Junta Directiva de la Asociación de Historia Contemporánea sobre el Plagio (Statement of the directive board of the Spanish Association of Contemporary History on plagiarism), in which it is stated:

A fin de cuentas, las notas al pie de página, que otorgan autoridad y reconocimiento a los autores citados, al mismo tiempo que seriedad y rigor a los profesionales que citan, siempre lo hacen en relación dialéctica con la corporación teóricamente universal de los historiadores [After all, footnotes, which confer authority and acknowledgement upon the authors cited and at the same time sensibility and rigorousness to the professionals who cite, always do this in a dialectic relation with the theoretically universal community of historians]. ${ }^{4}$

All in all, I might have assumed that historians using medical documentaries on SpanishAfrican colonies as keys for analyzing the early Francoist regime could miss my publications despite the easy access to them on the internet - because of their being written in Spanish. Sadly, Anglo-Saxon or French authors (to name but the most influential) often are unaware of and/or disregard the literature on certain topics published in journals or books from peripheral countries or written in languages less academically powerful than English or French. Maybe some of the authors publishing in Manguinhos - a journal which is to be justly praised because of its acceptance of texts written in languages such as Portuguese and Spanish - could tell their experiences about this. Personally, and despite having done medical history research on Morocco for over 15 years, I can say that some international researchers working on this topic have never used my contributions. However regrettable these facts are, the present case is actually the opposite. The authors of the paper are Spaniards, so it is easy for them to access and read my papers. In addition, I had a close professional relation to them and we are part of the same community of medical historians in Spain, so they are in the best position to know about my work.

In the end, this letter to the editor claims the importance of being cited. There are many things that rely on citing. Some have already been said; others, such as its weight in the career of researchers with non-permanent positions like myself, could be further developed. I think I have no right to bar other historians from doing research on topics which I have already studied, nor from using sources I have already worked with. I have no right to oblige them to share my methodology and interpretations. I think, however, I have the right to be cited by them if they work on those topics and use those sources, no matter the interpretations they propose or the methodology they follow. Otherwise, it is not only me but this journal and the community of historians at large that may be losing.

\footnotetext{
${ }^{4}$ Asociación de Historia Contemporánea. "Comunicado de la Junta Directiva de la Asociación de Historia Contemporánea sobre el Plagio." Available at: https://www.ahistcon.org/PDF/doc/Plagio.pdf.
} 